\title{
Effect of the two-stage thermal disintegration and anaerobic digestion of sewage sludge on the COD fractions
}

\author{
Anna Ciaciuch*, Jerzy Gaca, Karolina Lelewer \\ University of Science and Technology, Faculty of Chemical Technology and Engineering, Seminaryjna St. 3, 85-326 \\ Bydgoszcz, Poland \\ "Corresponding author: e-mail: anna.karczmarek@utp.edu.pl
}

\begin{abstract}
The research presents the changes in chemical oxygen demand (COD) fractions during the two-stage thermal disintegration and anaerobic digestion (AD) of sewage sludge in municipal wastewater treatment plant (WWTP). Four COD fractions have been separated taking into account the solubility of substrates and their susceptibility to biodegradation: inert soluble organic matter SI, readily biodegradable substrate SS, slowly biodegradable substrates XS and inert particulate organic material XI. The results showed that readily biodegradable substrates SS (46.8\% of total COD) and slowly biodegradable substrates XS (36.1\% of total COD) were dominant in the raw sludge effluents. In sewage effluents after two-stage thermal disintegration, the percentage of SS fraction increased to $90 \%$ of total COD and percentage of XS fraction decreased to $8 \%$ of total COD. After AD, percentage of SS fraction in total COD decreased to $64 \%$, whereas the percentage of other fractions in effluents increased.
\end{abstract}

Keywords: anaerobic digestion, COD fractions, effluents, sewage sludge, thermal disintegration.

\section{INTRODUCTION}

Anaerobic digestion (AD) is a commonly used method of sewage sludge stabilization, during which complex organic compounds undergo biodegradation as a result of microbial activity. Extracellular enzymes released by microorganisms pass into solution where both the dissolved particles and suspensions are hydrolyzed. This process proceeds in multi-stages until the monomers assimilated by microorganisms are formed. The hydrolysis of organic compounds is usually slower than the process of biological growth, therefore from the viewpoint of reaction rate, the hydrolysis stage is considered to be a limiting process of $\mathrm{AD}^{1}$. Therefore, in order to improve hydrolysis, the methods of sewage sludge pre-treatment are increasingly used, which aim is primarily to shorten fermentation time, increase the biogas production, improve the drainage and reduce the final amount of waste ${ }^{2,3}$. Therefore, in order to improve hydrolysis, the sewage sludge pre-treatment is more often applied before AD. The aim of these processes is primarily shortening the time of sewage sludge stabilization, increasing conversion of organic matter into biogas, improving dewatering performance and reduction of the final waste amount. These parameters depend largely on the contribution of substances susceptible to biodegradation in sewage sludge as well as on the method of sludge pre-treatment before $\mathrm{AD}$. The most often applied methods of disintegration are: sonication ${ }^{4,5}$, ozonation ${ }^{6}$, thermal disintegration ${ }^{1,7-9}$, microwave pre-treatment ${ }^{10,11}$ and acidic and alkaline hydrolysis ${ }^{12},{ }^{13}$. An action of the various disintegration methods consists in disruption of sludge flock structure and cell walls of microorganisms of the activated sludge. So, the content of microbial cells is released into the sludge liquid, and thus it is more readily available for microbial degradation ${ }^{14}$. It was observed that thermal hydrolysis replaced the stage of hydrolysis in the process of mesophilic anaerobic digestion ${ }^{3}$, caused increase in methane production and cut down time of $\mathrm{AD}^{15-18}$. Effectiveness of the individual methods of pretreatment is different and depends on many factors. In order to determine the effectiveness of sewage sludge disintegration, the various indicators are used, including among other: degree of disintegration (DD), reduction of particle size, efficiency of biogas production, COD solubilisation or rheological changes ${ }^{3,19-24}$.

A common indicator for monitoring the processes of waste treatment is chemical oxygen demand (COD). However, the total COD (tCOD) does not inform us what amount of organic compounds is susceptible to biodegradation. The organic substances flowing in together with the sewage occur in dissolved form or in suspension. These substances consist of biodegradable and non-biodegradable fractions. On this basis, the COD fraction were distinguished by solubility and susceptibility to biodegradation ${ }^{25-28}$. Substances, which undergo no changes or their biodegradation is so slow that they are considered to be non-degradable, are classified to the inert soluble organic matter fraction $(\mathrm{SI})^{29}$. These include among others, dissolved humic and fulvic acids and derivatives of biochemical conversions. The inert particulate organic material (XI) includes undissolved impurities supplied with sewage or being the products of biomass decay. It is assumed that during the biological processes of contamination removal, concentration of this fraction does not change. Contribution of biodegradable fractions (SS and XS) changes under the action of microorganisms and affects the oxygen demand. The SS fraction comprises easily biodegradable organic substances (volatile organic acids, alcohols, amino acids), which can be immediately assimilated and consequently, mineralized by heterotrophic organisms. Studies by Junoh et al. ${ }^{30}$ showed the increase in biogas production resulting from the increase of soluble components in the waste pre-treatment process. The fraction of slowly biodegradable substrates (XS) consists of complex organic particles (proteins, polysaccharides, lipides). These particles become assimilable by microorganisms after previous hydrolysis. It is estimated that content of XS and SS fractions in the raw sewage is totally $70 \%$ of $\mathrm{tCOD}^{31}$. The determination of COD fraction is gaining popularity because it allows for a more precise characterization of sewage and sludge composition and provides information on susceptibility 
to biodegradation of organic compounds contained in them $^{29,32}$. The ASM models and their modifications for the description of activated sludge become very popular in balancing the organic substrates and depending on the type of model, the various components in solubilized fractions and particulate can be identified ${ }^{33,34}$.

\section{MATERIAL AND METHODS}

\section{Two-stage thermal disintegration of sludge}

The sewage sludge and effluents were sampled from the municipal wastewater treatment plant in Bydgoszcz, Poland. Flow capacity of the wastewater treatment plant is: $43000 \mathrm{~m}^{3}$ of wastewater per day. The wastewater treatment plant is equipped with an installation for the thermal hydrolysis of sludge and the combined production of heat and electrical energy. The thermal disintegration of sludge is conducted in two stages. In the first stage, the raw sludge are subjected to an action of temperature of $90^{\circ} \mathrm{C}$ and pressure of 3 bar for $90 \mathrm{~min}$. In the second stage, the disintegration proceeds at temperature of $165^{\circ} \mathrm{C}$ and pressure of 6 bar for $20 \mathrm{~min}$. After cooling, sludge are pumped into the sludge digestion chamber. Digester operated in the mesophilic range. Studies on the effect of disintegration on the contribution of the individual fractions in tCOD were carried out using: effluents from raw sludge (RE), effluents after the first stage of disintegration (ETH1), effluents after the second stage of disintegration (ETH2) and effluents after anaerobic digestion (EAD). The physicochemical determinations (tCOD, BOD, TOC, TK, TP, $\mathrm{pH}$ ) were conducted for all the types of effluents and sludge. Sewage sludge and effluents were sampled in 12 series at weekly intervals. The tests were performed immediately after providing the samples to the laboratory.

\section{Studies on physicochemical properties of sewage sludge and effluents}

Chemical oxygen demand (tCOD) was determined by dichromate method, biochemical oxygen demand (BOD) was determined by manometric method using the measuring system OxiTop IS 12 (WTW, GmbH). Method of sample oxidation under supercritical conditions with NDIR detection and using TOC Sievers InnovOx analyzer was applied for the determination of total organic carbon (TOC). The $\mathrm{pH}$ was measured by the potentiometric method. The determinations of total Kjeldahl nitrogen (TKN) and total nitrogen (TN) were performed by the method of Koroleff mineralization and photometric detection with 2,6 dimethylphenol. The final determination was performed using the cuvette test LATON LCK 338 (HACH LANGE). Total phosphorus (TP) in sludge was analyzed according to PN-EN 14672:2006, the determination of TP in effluents was conducted by spectrophotometric method with phosphomolybdenic blue using the cuvette tests LATON LCK 350 (HACH LANGE). The determination of dry residue and water content consisted in determining the weight loss in sludge sample during drying to a constant weight at $105^{\circ} \mathrm{C}\left( \pm 5^{\circ} \mathrm{C}\right)$.

\section{Determination of COD fractions in effluents}

A method of balancing of COD fractions according to guidelines ATV-DVWK-A-131P $\mathrm{P}^{\mathbf{3 1}, \mathbf{3 5}}$ consisting in the determination of BOD and COD fractions in the filtered and unfiltered samples was applied in the studies. The tCOD value is the sum of COD particulates (xCOD) and COD solubilized fraction (sCOD):

$t C O D=x C O D+s C O D$

In turn, each of the mentioned fractions consists of degradable and slowly degradable fractions (inert). Thus, tCOD value can be described by the equation:

$t C O D=X S+X I+S S+S I$

Total chemical oxygen demand (tCOD) was determined in the raw effluents (RE), after the first stage of hydrolysis (ETH1), after the second stage of hydrolysis (ETH2) and after anaerobic digestion (EAD). Then, in order to determine the soluble fraction (sCOD), the effluent samples were filtrated through by a filter with porosity of $0.45 \mu \mathrm{m}$.

COD of non-degradable soluble fraction in raw effluents $\left(\mathrm{SI}_{\mathrm{r}}\right.$ ) can be roughly compared to COD of dissolved impurities after treatment stages $\left(\mathrm{SI}_{\mathrm{o}}\right)$.

$S I_{r}=S I_{o}$

Contribution of SI is 0.05 to 0.1 of total raw effluent $\operatorname{COD}\left(\mathrm{tCOD}_{\mathrm{r}}\right)$. For the municipal wastewater, the following assumption is accepted in calculations:

$S I=0.05 \cdot t C O D_{r}$

The solubilized, biologically easily degradable fraction (SS) was determined as a difference between concentration of degradable organic impurities (sCOD) and inert soluble organic matter (SI), according to formula:

$S S=s C O D-S I\left[\mathrm{mg} \mathrm{O}_{2} / \mathrm{L}\right]$

Fraction of slowly degradable organic suspensions was defined as a difference between BOD and fraction according to equation:

$X S=C B O D-S S\left[\mathrm{mg} \mathrm{O}_{2} / \mathrm{L}\right]$

where:

CBOD was calculated on the basis of experimental $\mathrm{BOD}_{5}$ of effluents. Kinetics of the first stage of disintegration is described by the first order equation:

$B O D t=C B O D\left(1-e^{-k t}\right)\left[\mathrm{mg} \mathrm{O}_{2} / \mathrm{L}\right]$

where:

$\mathrm{k}$ - rate constant, $\mathrm{d}^{-1}$. For substances contained in $\mathrm{mu}-$ nicipal wastes, it is within the range from 0.1 to $0.3 / \mathrm{d}$. It is accepted that its mean value is $0.23 / \mathrm{d}$.

CBOD - total carbon demand for the first stage of disintegration. By accepting $\mathrm{t}=5$ and $\mathrm{k}=0.23\left[\mathrm{~d}^{-1}\right]$, the simplified formula was obtained:

$C B O D=B O D_{5} / 0.6\left[\mathrm{mgO}_{2} / \mathrm{L}\right]$

Fraction XI was determined from a relationship:

$X I=A \cdot x C O D\left[\mathrm{mg} \mathrm{O}_{2} / 1\right]$

For the municipal wastes, coefficient $\mathrm{A}$ is 0.25 . Substituting relationship (9) into equation $x C O D=X S+$ $X I(10)$, we obtained:

$x C O D=X S / 0.75\left[\mathrm{mg} \mathrm{O}_{2} / \mathrm{L}\right]$ 


\section{RESULTS AND DISCUSSION}

\section{Balance of COD fractions in effluents}

The change in percentage contribution of the individual fractions in the effluent tCOD in the two-stage thermal disintegration and anaerobic digestion were presented in Figure 1. The raw effluents (RE) are characterized by a predominance of degradable compounds, both solubilized (SS), and in particulate (XS), which are totally $83 \%$ (SS 47\%, XS 36\%). It was observed that in effluents after the first stage of disintegration (ETH1), contribution of SS fraction in tCOD increased to $87.3 \pm 10.0 \%$, and after the second stage of disintegration (ETH2) content of this fraction was $88.9 \pm 5.5 \%$. It results that low-temperature thermal disintegration process $\left(90^{\circ} \mathrm{C}\right)$ causes the increase in content of solubilezed organic substances (SS) in hydrolyzate by $40 \%$. Similarly, Appels et al. ${ }^{\mathbf{3 6}}$ and Farno et al. ${ }^{37}$ showed the increase in content of solubilized COD at low temperature $\left(70-90^{\circ} \mathrm{C}\right)$ thermal treatment. The second stage of high-temperature disintegration $\left(165^{\circ} \mathrm{C}\right)$ has no effect on content of solubilized organic substances. Studies by Myszograj ${ }^{38}$ and Aboulfoth ${ }^{39}$ showed that $^{2}$ the highest increase of solubilized COD in total COD occurred during disintegration at temperature of $175^{\circ} \mathrm{C}$. However, these are the results of studies on one-stage disintegration process. The decrease in contribution of XS fraction in effluents after the two-stage disintegration was observed. Percentage of this fraction in ETH1 was $9.5 \pm 5,8 \%$, and in ETH2 $8.4 \pm 4.0 \%$, respectively. It is

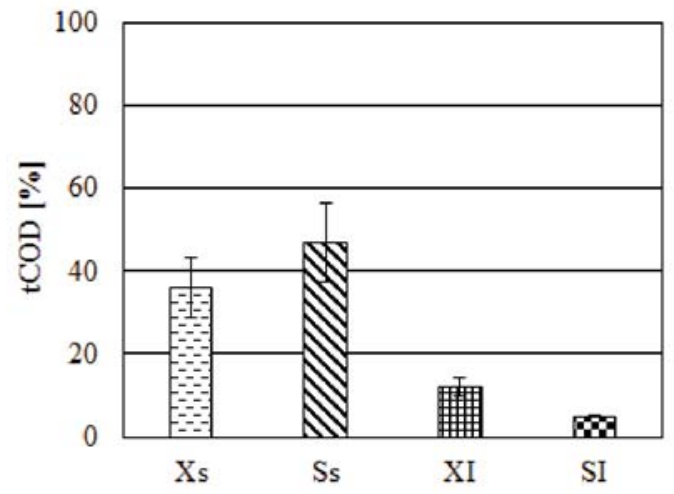

a)

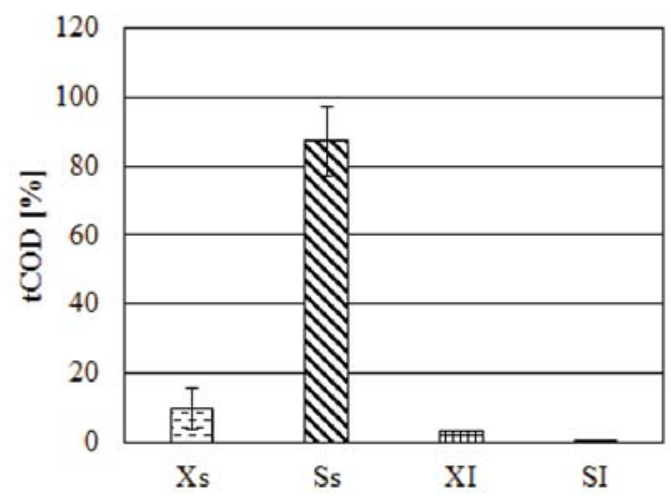

b) accepted that the hydrolysis products of XS fraction are readily biodegradable substances SS and inert soluble matter $\mathrm{SI}^{27,40}$. It can therefore be concluded that increase in contribution of SS fraction by $43 \%$ after two-stage thermal disintegration with respect to the raw effluents and simultaneous decrease in contribution of XS fraction by $28 \%$, indicates that in the thermal disintegration process, solid particles (colloids, suspensions) decompose to solubilized compounds which are easily assimilable organic carbon compounds. An increase in content of solubilized substances in thermal disintegration process was also observed by Aboulfoth et al. ${ }^{39}$ and Kumi et al. ${ }^{41}$ The inert fractions SI and XI represented the smallest contribution in all effluents studied. Percentage of the inert fractions (total SI and XI) was reduced during thermal disintegration from $17 \%$ in raw effluents (RE) to $2.9 \%$ in effluents after two-stage thermal disintegration $(\mathrm{ETH} 2)$. It results that treatment of sludge at high temperature and elevated pressure cause degradation of substances which are non-biodegradable. In effluents after $\mathrm{AD}$ (Fig. 1d), the decrease in contribution of SS fraction to $63.9 \pm 3.4 \%$ was observed, i.e. decrease with respect to ETH2 by about $20 \%$. It proves that microorganisms use the readily degradable substances as substrates for biogas production in the process of anaerobic digestion.

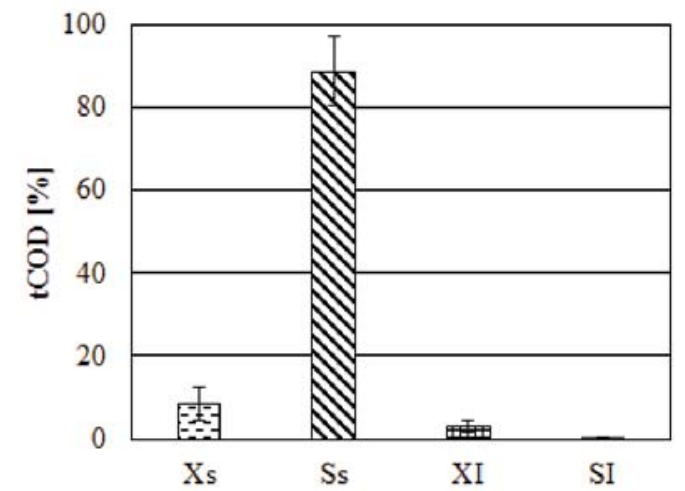

c)

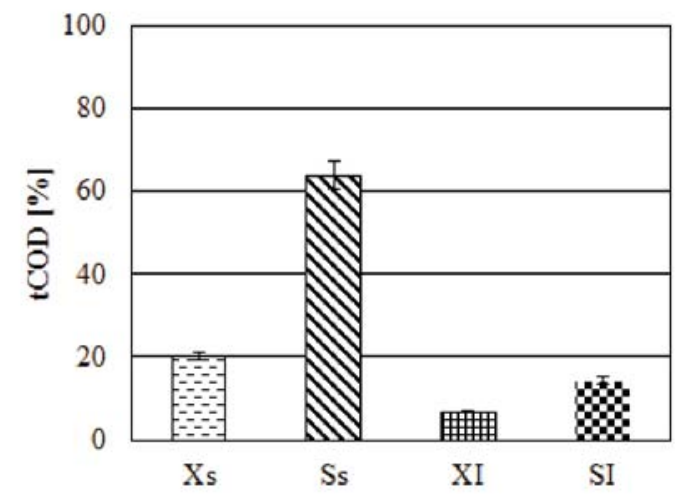

d)

Figure 1. Percentage contribution of COD fractions in effluents from sludge: a) in the raw effluents (RE), b) in effluents after the I-st stage of disintegration (ETH1), c) after the II-nd stage of disintegration (ETH2), d) after AD (EAD) (mean of 12 measurements \pm S.D 
Changes in physicochemical properties of sewage sludge and effluents

Physicochemical characteristic of sludge was presented in Table 1. A mean values of tCOD, BOD and TOC in sludge after the I-st stage of disintegration (STH1) and after the II-nd stage of disintegration (STH2) were not significantly changed with respect to raw sludge (RS). Also Farno et al. ${ }^{37}$ pointed out that tCOD is unchanged in disintegration process. It was observed that the values of these parameters vary within a wide range. It was found that after $\mathrm{AD}$, the $\mathrm{tCOD}, \mathrm{BOD}$ and TOC loads were reduced with respect to sludge after the II-nd stage of disintegration (STH2) by 46, 99 and 51\%, respectively. A significant reduction of the organic matter load in methane fermentation process, particularly BOD to $1.7 \mathrm{~g}$ $\mathrm{O}_{2} / \mathrm{kg} \mathrm{DM}$, indicates a high degree of disintegration of biodegradable organic compounds and mineralization of organic matter. The mean TKN concentration in sludge in two-stage thermal disintegration was insignificantly changed and it was within the range from 18.1 to 21.6 $\mathrm{g} / \mathrm{kg}$ DM. The TP value in raw sludge (RS), after the I-st stage of disintegration (STH1) and after the II-nd stage of disintegration (STH2), also was unchanged and its mean value was from 22.4 to $25.6 \mathrm{~g} / \mathrm{kg}$ DM. In AD process, the increase of both indicators in sewage sludge occured (TKN $61.3 \mathrm{~g} / \mathrm{kg}$ DM, TP $38.1 \mathrm{~g} / \mathrm{kg} \mathrm{DM}$ ).

In effluents after two-stage thermal disintegration (ETH2), a several fold increase in tCOD, BOD and TOC load was observed relative to raw effluents (RE) (Table 2). Since the total content of these parameters in sewage sludge remained unchanged in the thermal disintegration process, this indicates a change of the form organic compounds. It demonstrates that during thermal disintegration, destruction of solid particles and decomposition of organic high molecular compounds to solubilized organic compounds occurs and these compound pass into sludge liquid. In $\mathrm{AD}$ process, a reduction of load of organic compounds occurred what is a measure of the fermentation process efficiency. Reduction of tCOD load in effluents was $78 \%$ and in sludge $46 \%$. Reduction of TOC load in effluents was $81 \%$, in sludge $51 \%$. High reduction of BOD load in effluents from sludge in $\mathrm{AD}$ process $(97.9 \%)$ proves about the presence of readily degradable low molecular organic compounds in a feedstock to fermenter. Increase in tCOD/BOD ratio in sewage sludge proves about a good utilization of organic substrates in AD process (Table 1) and in effluents (Table 2). The higher are the values of this ratio, the more slowly degradable and non-degradable substrates is in the sludge mass (calculated on dry matter) ${ }^{\mathbf{4 2}, \mathbf{4 3}}$.

\section{SUMMARY}

The paper describes the studies on an effect of twostage thermal disintegration of sludge on changes in COD fractions in effluents. Attention was paid to the fractions of solubilized organic compounds in effluents, the content of which affects process of anaerobic digestion by methanogenic bacteria. It was found that in effluents after the I-st stage of disintegration (ETH1) $\left(90^{\circ} \mathrm{C}\right)$, percentage of solubilized COD fraction increased by $40 \%$ with respect to raw effluents (RE). However, the II-nd stage of disintegration proceeding at temperature of $165^{\circ} \mathrm{C}$ does not change content of solubilized substances. Changes in contribution of the individual COD fractions were studied for samples with a high variability of COD, BOD and TOC indicators (Table 1, Table 2). Despite that, it was found that the percentage of the individual COD fractions in effluents remained stable throughout all the study period (SD below 10\%). Studies are important because they were carried out in technological full-scale and reflect an actual course of changes in forms of organic compounds in the thermal disintegration of sewage sludge.

Table 1. Characteristic of sludge (mean value and range)

\begin{tabular}{|c|c|c|c|c|c|c|c|c|}
\hline Sample & $\begin{array}{c}\text { tCOD } \\
{[\mathrm{g} / \mathrm{kg} \text { of } \mathrm{DM}]}\end{array}$ & $\begin{array}{c}\text { BOD } \\
{[\mathrm{g} / \mathrm{kg} \text { of } \mathrm{DM}]}\end{array}$ & tCOD/BOD & $\begin{array}{c}\text { TOC } \\
{[\mathrm{g} / \mathrm{kg} \text { of } \mathrm{DM}]}\end{array}$ & $\begin{array}{c}\text { TKN } \\
{[\mathrm{g} / \mathrm{kg} \text { of } \mathrm{DM}]}\end{array}$ & $\begin{array}{c}\text { TP } \\
{[\mathrm{g} / \mathrm{kg} \text { of } \mathrm{DM}]}\end{array}$ & $\begin{array}{l}\mathrm{DM} \\
{[\%]}\end{array}$ & $\mathrm{pH}$ \\
\hline RS & $\begin{array}{l}1382.6 \\
728.2-2366\end{array}$ & $\begin{array}{c}332.8 \\
247.0-444.4\end{array}$ & 4.15 & $\begin{array}{l}261.2 \\
210.3-331.9\end{array}$ & $\begin{array}{l}21.6 \\
13.3-28.6\end{array}$ & $\begin{array}{l}23.2 \\
21.3-25.2\end{array}$ & $\begin{array}{l}14.5 \\
8.25-19.4\end{array}$ & $\begin{array}{l}6.1 \\
4 .-7.3\end{array}$ \\
\hline STH1 & $\begin{array}{l}1122.6 \\
410.3-1774\end{array}$ & $\begin{array}{c}330.1 \\
281.8-405.8\end{array}$ & 3.40 & $\begin{array}{l}308.6 \\
214.9-381.0\end{array}$ & $\begin{array}{l}20.9 \\
17.2-24.5\end{array}$ & $\begin{array}{l}25.6 \\
24.5-28.1\end{array}$ & $\begin{array}{l}12.0 \\
8.51-15.0\end{array}$ & $\begin{array}{l}6.4 \\
5.3-7.6\end{array}$ \\
\hline STH2 & $\begin{array}{l}1182.7 \\
632.4-2286\end{array}$ & $\begin{array}{c}335.1 \\
187.5-509.1\end{array}$ & 3.53 & $\begin{array}{l}294.5 \\
216.0-394.1\end{array}$ & $\begin{array}{l}18.1 \\
9.20-34.5\end{array}$ & $\begin{array}{l}22.4 \\
21.2-24.6\end{array}$ & $\begin{array}{l}8.66 \\
4.79-14.6\end{array}$ & $\begin{array}{l}6.5 \\
5.4-7.4\end{array}$ \\
\hline SAD & $\begin{array}{l}643.2 \\
283.0-880.5\end{array}$ & $\begin{array}{l}1.7 \\
1.5-2.3\end{array}$ & 378 & $\begin{array}{l}144.9 \\
82.4-232.2\end{array}$ & $\begin{array}{l}61.3 \\
42.9-102.7\end{array}$ & $\begin{array}{l}38.1 \\
33.6-45.3\end{array}$ & $\begin{array}{l}4.89 \\
4.00-7.56\end{array}$ & $\begin{array}{l}7.2 \\
6.9-7.5\end{array}$ \\
\hline
\end{tabular}

$\mathrm{RS}$ - raw sludge, STH1 - sludge after the I-st stage of thermal disintegration,

$\mathrm{STH} 2$ - sludge after the II-nd stage of thermal disintegration, SAD - sludge after AD

Table 2. Characteristic of effluents from sludge (mean value and range)

\begin{tabular}{|c|c|c|c|c|c|c|c|c|c|}
\hline Sample & $\begin{array}{l}\text { tCOD } \\
{[\mathrm{mg} / \mathrm{L}]}\end{array}$ & $\begin{array}{c}\mathrm{BOD} \\
{[\mathrm{mg} / \mathrm{L}]}\end{array}$ & tCOD/BOD & $\begin{array}{c}\text { TOC } \\
{[\mathrm{mg} / \mathrm{L}]}\end{array}$ & $\begin{array}{c}\mathrm{TN} \\
{[\mathrm{mg} / \mathrm{L}]}\end{array}$ & $\begin{array}{c}\text { TP } \\
{[\mathrm{mg} / \mathrm{L}]}\end{array}$ & $\mathrm{pH}$ & $\begin{array}{l}\mathrm{sCOD} \\
{[\mathrm{mg} / \mathrm{L}]}\end{array}$ & $\begin{array}{l}\mathrm{xCOD} \\
{[\mathrm{mg} / \mathrm{L}]}\end{array}$ \\
\hline RE & $\begin{array}{c}687.6 \\
380.8-1282\end{array}$ & $\begin{array}{c}350.9 \\
200.0-500.0\end{array}$ & 1.96 & $\begin{array}{c}123.3 \\
80.6-190\end{array}$ & $\begin{array}{c}74.8 \\
62.8-90.2\end{array}$ & $\begin{array}{c}46.8 \\
21.5-67.8\end{array}$ & $\begin{array}{c}6.7 \\
6.3-7.0\end{array}$ & 283.87 & 361.82 \\
\hline ETH2 & $\begin{array}{c}32994 \\
25957-37931\end{array}$ & $\begin{array}{c}17000 \\
14000-24000\end{array}$ & 1.94 & $\begin{array}{c}8164 \\
3695-12116\end{array}$ & $\begin{array}{c}2185 \\
976.0-2904\end{array}$ & $\begin{array}{c}201.5 \\
140.0-227.0\end{array}$ & $\begin{array}{c}6.0 \\
5.4-6.4\end{array}$ & 30234 & 3910.1 \\
\hline EAD & $\begin{array}{c}7418 \\
2019-14663\end{array}$ & $\begin{array}{c}362.0 \\
222.0-500.0\end{array}$ & 20.5 & $\begin{array}{c}1526 \\
788.5-3168\end{array}$ & $\begin{array}{c}2136 \\
2103-2190\end{array}$ & $\begin{array}{c}122.8 \\
62.80-224.0\end{array}$ & $\begin{array}{c}6.8 \\
5.1-8.1\end{array}$ & 4821.4 & 2700.8 \\
\hline
\end{tabular}

$\mathrm{RE}$ - effluents from raw sludge, ETH2 - effluents from sludge after two-stage thermal disintegration, EAD - effluents from sludge after AD 


\section{ABBREVIATIONS}

$\begin{array}{ll}\text { BOD } & - \text { total biochemical oxygen demand }[\mathrm{mg} / \mathrm{L}] \\ \text { tCOD } & - \text { total chemical oxygen demand }[\mathrm{mg} / \mathrm{L}] \\ \text { TOC } & \text { - total organic carbon }[\mathrm{mg} / \mathrm{L}] \\ \text { DS } & - \text { dry solids }[\%] \\ \text { TKN } & - \text { total Kjeldahl nitrogen }[\mathrm{g} / \mathrm{kg} \text { of } \mathrm{DS}] \\ \text { TN } & - \text { total nitrogen }[\mathrm{mg} / \mathrm{L}] \\ \text { TP } & - \text { total phosphorus }[\mathrm{mg} / \mathrm{L}] \\ \mathrm{CBOD} & - \text { carbonaceous oxygen demand }[\mathrm{mg} / \mathrm{L}] \\ \mathrm{BOD}_{5} & - \text { biochemical oxygen demand that is exerted } \\ \text { over the five day period } \\ \text { tCOD }_{\mathrm{r}} \text { - total chemical oxygen demand in raw effluents }\end{array}$

\section{Fractions of COD}

sCOD - soluble chemical oxygen demand $[\mathrm{mg} / \mathrm{L}]$

xCOD - particulate chemical oxygen demand $[\mathrm{mg} / \mathrm{L}]$

SS - readily biodegradable substrate,

SI - inert soluble organic matter,

XS - slowly biodegradable substrates,

XI - inert particulate organic material.

\section{LITERATURE CITED}

1. Climent, M., Ferrerb, I., del Mar Baezac, M., Artola, A., Vázquezb, F. \& Font, X. (2007). Effects of thermal and mechanical pretreatments of secondary sludge on biogas production under thermophilic conditions. Chem. Eng. J. 133, 335-342. DOI: 10.1016/j.cej.2007.02.020.

2. Zhang, H. (2010). Sludge treatment to increase biogas production. Trita-LWR Degree Project 10-20, Stockholm, Sweden.

3. Foladori, P., Andreottola, G. \& Ziglio, G. (2010). Sludge reduction technologies in wastewater treatment plants. IWA Publishing, London.

4. Bougrier, C., Carrere, H. \& Delgenes, J. (2005). Solubilisation of waste-activated sludge by ultrasonic treatment. Chem. Eng. J. 106, 163-169. DOI: 10.1016/j.cej.2004.11.013.

5. Zhang, P., Zhang, G. \& Wang, W. (2007). Ultrasonic treatment of biological sludge: Floc disintegration, cell lysis and inactivation. Bioresource Technol. 98, 207-210. DOI: 10.1016/j. biortech.2005.12.002.

6. Zhang, G., Yang, J., Liu, H. \& Zhang, J. (2009). Sludge ozonation: Disintegration, supernatant changes and mechanisms. Bioresource Technol. 100, 1505-1509. DOI: 10.1016/j. biortech.2008.08.041.

7. Neyens, E. \& Baeyens, J. (2003). A review of thermal sludge pre-treatment processes to improve dewaterability. J. Hazard. Mater. B98, 51-67. DOI: 10.1016/S0304-3894(02)00320-5.

8. Pilli, S., Yan, S., Tyagi, R.D. \& Surampalli, R.Y. (2015). Thermal pretreatment of sewage sludge to enhance anaerobic digestion: A review. Crit. Rev. Environ. Sci. Technol. 45(6), 669-702. DOI: 10.1080/10643389.2013.876527.

9. Ferrer, I., Ponsá, S., Vázquez, F. \& Font, X. (2008). Increasing biogas production by thermal $\left(70^{\circ} \mathrm{C}\right)$ sludge pre-treatment prior to thermophilic anaerobic digestion. Biochem. Eng. J. 42, 186-192. DOI: 10.1016/j.bej.2008.06.020.

10. Appels, L., Houtmeyers, S., Degrève, J., Impe, J.V. \& Dewil, R. (2013). Influence of microwave pre-treatment on sludge solubilization and pilot scale semi-continuous anaerobic digestion. Bioresource Technol. 128, 598-603. DOI: 10.1016/j. biortech.2012.11.007.

11. Tyagi, V. \& Lo, S. (2013). Microwave irradiation: A sustainable way for sludge treatment and resource recovery. Renew. Sust. Energ. Rev. 18, 288-305. DOI: 10.1016/j.rser.2012.10.032.

12. Li, H., Li, C., Liu, W. \& Zou, S. (2012). Optimized alkaline pretreatment of sludge before anaerobic digestion. Bioresource Technol. 123, 189-194. DOI: 10.1016/j.biortech.2012.08.017.
13. Zhang, Y., Zhang, P. Zhang, G. Ma, W. Wu, H. \& Ma, B. (2012). Sewage sludge disintegration by combined treatment of alkaline + high pressure homogenization. Bioresource Technol. 123, 514-519. DOI: 10.1016/j.biortech.2012.07.078.

14. Eskicioglu, C., Kennedy, K. \& Ronald, D.R. (2006). Characterization of soluble organic matter of waste activated sludge before and after thermal pretreatment. Water Res. 40, 3725-3736. DOI: 10.1016/j.watres.2006.08.017.

15. Cui, R. \& Jahng, D. (2006). Enhanced methane production from anaerobic digestion of disintegrated and deproteinized excess sludge. Biotechnol. Lett. 28, 531-538. DOI: 10.1007/ s10529-006-0012-9.

16. Carlson, M., Lagerkvist, A. \& Morgan-Sagastume, F. (2012). The effect of substrate pre-treatment on anaerobic digestion system: A review. Waste Management. 32, 1634-1650. DOI: 10.1016/j.wasman.2012.04.016.

17. Martínez, E., Rosas, J., Morán, A. \& Gómez, X. (2015). Effect of ultrasound pretreatment on sludge digestion and dewatering characteristics: Application of particle size analysis. Water 7(11), 6483-6495. DOI: 10.3390/w7116483.

18. Wu, Q.L., Guo, W.Q., Zheng, H.S., Luo, H.Ch., Feng, X.Ch., Yin, R.L. \& Ren, N.Q. (2016). Enhancement of volatile fatty acid production by co-fermentation of food waste and excess sludge without $\mathrm{pH}$ control: The mechanism and microbial community analyses. Bioresource Technol. 216, 653-660. DOI: 10.1016/j.biortech.2016.06.006.

19. Huan, L., Yiying, J., Bux Mahar, R., Zhiyu, W. \& Yongfeng, N. (2009). Effects of ultrasonic disintegration on sludge microbial activity and dewaterability. J. Hazard. Mater. 161, 1421-1426. DOI: 10.1016/j.jhazmat.2008.04.113.

20. Xiao, B.Y. \& Liu, J.X. (2009). Effects of various pretreatments on biohydrogen production from sewage sludge. Chin. Sci. Bull. 54, 2038-2044. DOI: 10.1007/s11434-009-0100-z.

21. Jung, Y., Ko, H., Jung, B. \& Sung, N. (2011). Application of ultrasonic system for enhanced sewage sludge disintegration: A comparative study of Single- and dual- frequency. KSCE $J$. Civ. Eng. 15, 793-797. DOI: 10.1007/s12205-011-0832-6.

22. Negral, L., Marañón, E., Castrillón, L. \& Fernández-Nava, Y. (2015). Differences in soluble COD and ammonium when applying ultrasound to primary, secondary and mixed sludge. Water Sci. Technol. 71, 1398-406. DOI: 10.2166/wst.2015.113.

23. Jin, L., Zhang, G. \& Zheng, X. (2015). Effects of different sludge disintegration methods on sludge moisture distribution and dewatering performance. J. Environ. Sci. 28, 22-28. DOI: 10.1016/j.jes.2014.06.040.

24. Penaud, V., Delgene`s, J.P. \& Moletta, R. (1999). Thermochemical pretreatment of a microbial biomass: influence of sodium hydroxide addition on solubilization and anaerobic biodegradability. Enzyme Microb. Tech. 25, 258-263. DOI: 10.1016/S0141-0229(99)00037-X.

25. Sperling, M. (2007). Basic principles of wastewater treatment. IWA Publishing, Vol. 2, London.

26. Zawilski, M. \& Brzezińska, A. (2009). Variability of COD and TKN fractions of combined wastewater. Pol. J. Environ. Stud. 18, 501-505.

27. Henze, M., Gujer, W., Mino, T. \& van Loosdrecht, M. (2007). Activated sludge models ASM1, ASM2, ASM2d, ASM3. IWA Tasc Group on Mathematical Modelling for Design and Operation of Biological Wastewater Treatment, London.

28. Dulekgurgen, E., Doğruel, S., Karahan, Ö. \& Orhon, D. (2006). Size distribution of wastewater COD fractions as an index for biodegradability. Water Res. 40, 273-282. DOI: 10.1016/j.watres.2005.10.032.

29. Hayet, C., Saida, B.A., Touhami, Y. \& Hedi, S. (2016). Study of biodegradability for municipal and industrial Tunisian wastewater by respirometric technique and batch reactor test. Sustain. Environ. Res. 26, 55-62. DOI: 10.1016/j.serj.2015.11.001.

30. Junoh, H., Yip, CH. \& Kumaran, P. (2016). Effect on $\mathrm{Ca}(\mathrm{OH})_{2}$ pretreatment to enhance biogas production of organic food waste, International Conference on Advances in Renew- 
able Energy and Technologies (ICARET 2016), IOP Publishing, IOP Conf. Series: Earth and Environmental Science, Vol. 32. Putrajaya, Malaysia. DOI: 10.1088/1755-1315/32/1/012013.

31. Sadecka, Z., Jędrczak, A. \& Płuciennik-Koropczuk, E. (2013). COD Fractions in Sewage Flowing into Polish Sewage Treatment Plants. Chem. Biochem. Eng. Q. 27(2), 185-195.

32. Wentzel, M.C., Mbewe, A., Lakay, M.T. \& Ekama, G.A. (1999). Batch test for characterisation of the carbonaceous materials in municipal wastewaters. Water SA. 25(3), 327-335.

33. Henze, M., Gujer, W., Mino, T. \& von Loosdrecht, M. (2000). Activated sludge models ASM1, ASM2, ASM2d and ASM3. IWA Task Group on Mathematical Modelling for Design and Operation of Biological Wastewater Treatment; IWA Scientific and Technical Reports, London.

34. Wintle, B. (2008). The use of activated sludge model No. 3 to model an activated sludge unit at an industrial wastewater treatment facility. Master of Science. Environmental Engineering Oklahoma State University Stillwater, Oklahoma.

35. Specialized Committees ATV-DVWK. ATV-DVWK A131P. (2000). Dimensioning of biological activated treatment plant (in Polish). Seidel-Przywecki. Warsaw.

36. Appels, L., Degrèvea, J., Bruggen, B., Impe, J. \& Dewil R. (2010). Influence of low temperature thermal pre-treatment on sludge solubilisation, heavy metal release and anaerobic digestion, Bioresource Technol. 101(15), 5743-5748. DOI: 10.1016/j.biortech.2010.02.068.

37. Farno, E., Baudez, J.C., Parthasarathy, R. \& Esshtiaghi, N. (2016). Impact of thermal treatment on the rheological properties and composition of waste activates sludge: COD solubilisation as a footprint of rheological changes. Chem. Eng. J. 295, 39-48. DOI: 10.1016/j.cej.2016.03.022.

38. Myszograj, S. (2013). Effects of the solubilisation of the COD of municipal waste in thermal disintegration. Arch. Environ. Protect. 39(2), 57-67. DOI: 10.2478/aep-2013-0014.

39. Aboulfoth, A.M., El Gohary, E.H. \& El Monayeri, O.D. (2015). Effect of thermal pretreatment on the solubilization of organic matters in a mixture of primary and waste activated sludge. J. Urban Environ. Eng. 9(1), 82-88. DOI: 10.4090/ juee.2015.v9n1.082088.

40. Henze, M., Gujer, W., Mino, T., Matsuo, T., Wentzel, M.C., Marais, G.v.R. \& Van Loosdrecht, M.C. (1999). Activated sludge model No2D, ASM2D. Water Sci. Technol. 39(1), 165-182. DOI: 10.1016/S0273-1223(98)00829-4.

41. Kumi, P.J., Henley, A., Shana, A., Wilson, W. \& Esteves, S.R. (2016). Volatile fatty acids platform from thermally hydrolysed secondary sewage sludge enhanced through recovered micronutrients from digested sludge. Water Res. 100, 267-276. DOI: 10.1016/j.watres.2016.05.030.

42. Mikosz, J. (2015). Determination of permissible industrial pollution load at a municipal wastewater treatment plant. Int. J. Environ. Sci. Technol. 12, 827-836. DOI: 10.1007/s13762013-0472-0.

43. Penn, M.R., Pauer, J.J. \& Mihelcic, J.R. (2009). Biochemical oxygen demand. Environ. Ecol. Chem. 2, 278-297. 